\title{
Development of a Wide Spectrum Microbicide Basant and Three Meritorious Strains of Probiotic Iactobacilli for Restoration and Maintenance of Healthy Vagina
}

\author{
GP Talwar* and Jagdish C Gupta \\ Talwar Research Foundation, India \\ Submission: January 19, 2017 ; Published: May 02, 2017 \\ *Corresponding author: Talwar GP, Research Foundation, E-8, Neb Valley, Neb Sarai, New Delhi-110068, India, Tel: +91-011-65022405; \\ Email: gptalwar@gmail.com
}

\begin{abstract}
We report here two valuable Products useful for preventing not only a variety of sexually transmitted infections, but also treating very effectively 95\% cases of recurring episodes of Vaginosis. These are 3 strains of Probiotics, L. fermentum TRF \# 36, L. salivarius TRF \# 30 and L. gasseri TRF \# 8, which secrete high amounts of Lactic acid and have high hydrophobicity. They make $\mathrm{H}_{2} \mathrm{O}_{2}$ and Bacteriocins, and contain Arginine deiminase, preventing foul odour. The second Product is a wide spectrum Polyherbal microbicide BASANT. It inhibits every strain of $N$. gonorrhoeae tested including those resistant to antibiotics and other drugs as well as C. albicans, C. glabrata and C. tropicalis. It prevents the growth of free and cell bound Chlamydia trachomatis. It prevents the entry of HPV-16 in Hela cells. It inhibits both CCR4 and CCR5 tropic clades of HIV. An interesting property of BASANT is to eliminate HPV-16 from infected cervical cells at early C1N stage on path to carcinoma of cervix, restoring to normalcy the cervix and Pap smear.
\end{abstract}

\section{Foreword}

An essential trait of living organisms is their ability to reproduce. In humans, this basic function is mainly performed by women, even though males contribute sperms to fertilize the ovum.

Vagina is an extraordinary organ. The $\mathrm{pH}$ of healthy vagina is between 3.8 and 4.5 in contrast to the rigorously maintained $\mathrm{pH}$ of 7.4 of the body. This is made possible by in situ harmonious residence of a special type of bacteria, the Probiotic Lactobacilli on the endometrial cells of the vagina. These bacilli make and secrete Lactic acid to render the $\mathrm{pH}$ acidic locally, discouraging the growth of several aerobic and anaerobic micro-organisms. Several strains of lactobacilli make and secrete also H2O2 (Hydrogen peroxide) a mild local antiseptic, and Bacteriocins with anti-bacterial properties. Lactobacilli also carry an enzyme Arginine deiminase, which prevents the making of derivatives of foul odour. With all these properties, lactobacilli play a vital role in maintenance of healthy odour- free vagina.

\section{Probiotics lactobacilli}

All Lactobacilli are not identical. A number of strains of lactobacilli inhabiting vagina have been identified. We isolated over 200 strains of lactobacilli from healthy vagina of 80 women with informed consent and after ethical approval. These were characterized by employing species specific primers followed by sequencing of $16 \mathrm{~S}$ rDNA [1]. Isolates of the same species were differentiated by Random Amplified Polymorphic DNA (RAPD) profiles. All isolates were gram positive, catalase negative bacilli. All lactobacilli gave a $200 \mathrm{bp}$ amplicon by genus specific PCR (Figure 1).

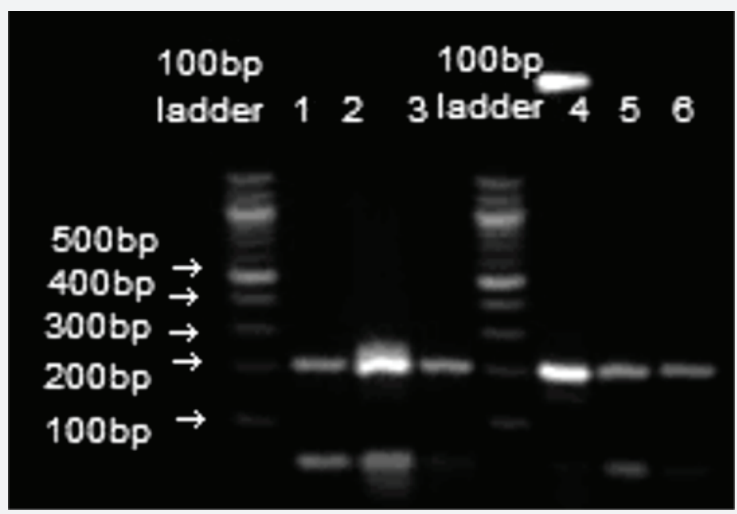

Figure 1: Representative genus specific PCR products of 6 isolates (lanes 1-3, 4-6) on agarose gel electrophoresis. All isolates gave a 200bp amplicon (adapted from 1). 
Characterization of each species could be done by PCR employing species specific primers. Figure 2 is an example of results obtained enabling identification of 10 species of lactobacilli isolated from healthy vagina. Whereas Lactobacillus jensenii, Lactobacillus gasseri, Lactobacillus rhamnosus and Lactobacillus delbrukii are common in USA, Canada and Europe, Lactobacillus reuteri, Lactobacillus fermentum and Lactobacillus salivarius, are dominant in India (Table 1).

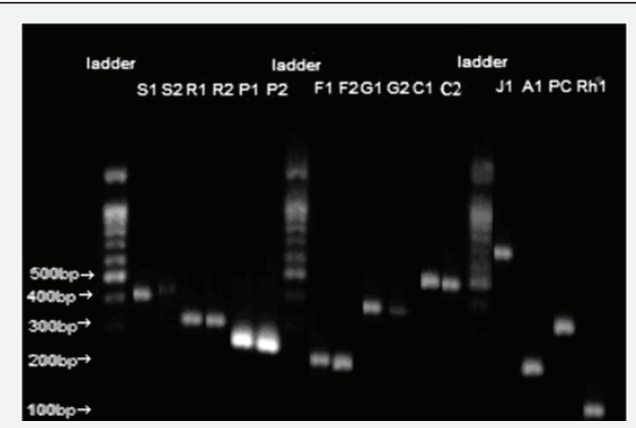

Figure 2: Figure 2: Species specific PCR products of the 10 species of Lactobacilli isolated from healthy vagina. This representative figure shows the profiles of 2 isolates of each of the 6 species and 1 isolate of the rest of 4 species as viewed on $2 \%$ agarose gel. S1 and S2, L. salivarius strains, 400bp amplicon; $\mathrm{R} 1$ and $R 2$, L. reuteri strains, 300bp amplicon, $\mathrm{P} 1$ and P2, L. plantarum strains, 250bp amplicon; F1 and F2, L. fermentum strains, 200bp amplicon; G1 and G2, L. gasseri strains, 350bp product; C1 and C2, L. crispatus strains, 500bp PCR amplicon; J1, L. jensenii, 700bp amplicon; A1, L. acidophilus, 200bp PCR amplicon; PC, L. paracasei, 300bp amplicon; Rh1 L. rhamnosus, 100bp amplicon (adapted from 1).

Table 1: Lactobacillus species isolated from healthy vagina of women $(\mathrm{n}=80)$ (adapted from 1).

\begin{tabular}{|c|c|c|}
\hline \multirow{2}{*}{ Group } & Species & $\begin{array}{c}\text { Number of Isolates Identified } \\
(\%)\end{array}$ \\
\hline \multirow{2}{*}{ Group IV: } & L. reuteri & $26(32.5 \%)$ \\
\hline \multirow{3}{*}{64 women } & L. fermentum & $20(25 \%)$ \\
\cline { 2 - 3 } & L. salivarius & $13(16.25 \%)$ \\
\cline { 2 - 3 } & L. plantarum & $5(6.25 \%)$ \\
\hline \multirow{2}{*}{ Group II: } & L. crispatus & $4(5 \%)$ \\
\hline \multirow{3}{*}{11 women } & L. jensenii & $3(3.75 \%)$ \\
\cline { 2 - 3 } & L. gasseri & $2(2.5 \%)$ \\
\cline { 2 - 3 } & L. acidophilus & $2(2.5 \%)$ \\
\hline \multirow{2}{*}{ Group III: } & L. casei & $0(0)$ \\
\hline \multirow{2}{*}{5 women } & L. paracasei & $1(1.25 \%)$ \\
\cline { 2 - 3 } & L. rhamnosus & $4(5 \%)$ \\
\hline Group I: & L. delbruckii & $0(0)$ \\
\hline
\end{tabular}

\section{Differential properties of strains within a species}

A surprising observation was that all strains within a given species are not identical in the amount of Lactic acid made by them and in various other properties, such as hydrophobicity, ability to make $\mathrm{H}_{2} \mathrm{O}_{2}$ and Bacteriocins. Figure 3 is a representative illustration of the vast difference in the amount of D-lactic acid produced and secreted by them [2]. Lactic acid is essential to maintain the acidic $\mathrm{pH}$ of vagina. Whereas lactobacilli secrete both $\mathrm{D}$ and $\mathrm{L}$ isomers of lactic acid, L-lactic acid gets further metabolized. It is thus the D-lactic acid made by the resident lactobacilli that contributes to making and retaining the acidic $\mathrm{pH}$ of vagina.

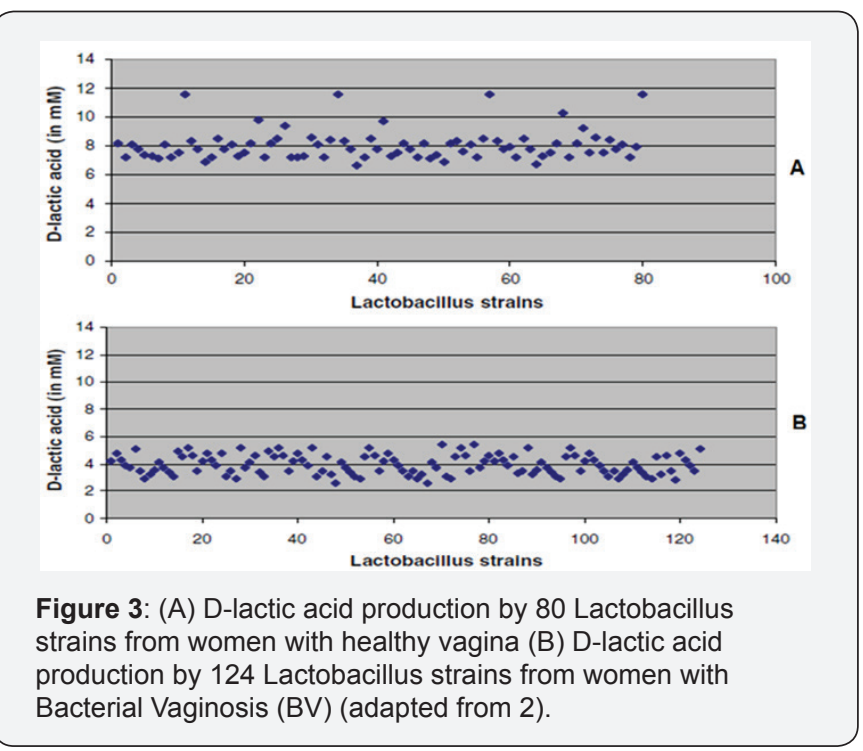

\section{Selection of Meritorius strains of Lactobacillus}

On basis of possessing desirable properties of secreting high amounts of lactic acid, high hydrophobicity, making $\mathrm{H}_{2} \mathrm{O}_{2}$ and Bacteriocins, and having Arginine deiminse, the enzyme preventing foul odour derivatives, we selected 3 strains of Lactobacilli. These were L. salivarius TRF \# 30, L. fermentum TRF \# 36, and L. gasseri TRF \# 8. These have been patented and deposited in an International Depository at Microbial Culture Collection and Gene Bank (MTCC), who have assigned numbers for these strains: L. gasseri (MTCC 5615), L. salivarius (MTCC 5616) and L. fermentum (MTCC 5617). These have been transferred to a company M/s Microbax Hyderabad, India who have competence to culture these on mass scale, lyophilize the bacilli along with stabilizers and package these in easily dissolvable capsules, insertable conveniently by women in the vagina.

\section{A Wide spectrum microbicide, BASANT}

We developed a polyherbal microbicide composed of $95 \%$ purified Curcumin (Figure 4), purified extracts of Amla (Emblica officinalis), Aloe vera, and Neem leaves (Azadirachta indica) along with pharmacologically approved excipients and preservatives [3]. BASANT was formulated as cream and in powder form, the latter encapsulated in an easily insertable in vagina capsule. This formulation has an anti-microbial action on a wide spectrum of microorganisms that infect vagina. It inhibits the growth of all strains of $N$. gonorrhoeae examined whether from WHO or from STD clinics, including those resistant to penicillin, tetracycline, 


\section{Journal of Gynecology and Women's Health}

nalidixic acid and ciprofloxacin. Table 2 recapitulates this property. It has inhibitory action against Candida glabrata, Candida albicans and Candida tropicalis isolated from women

with vulvovaginal candidiasis, including strains resistant to azole drugs and amphotericin B (3).

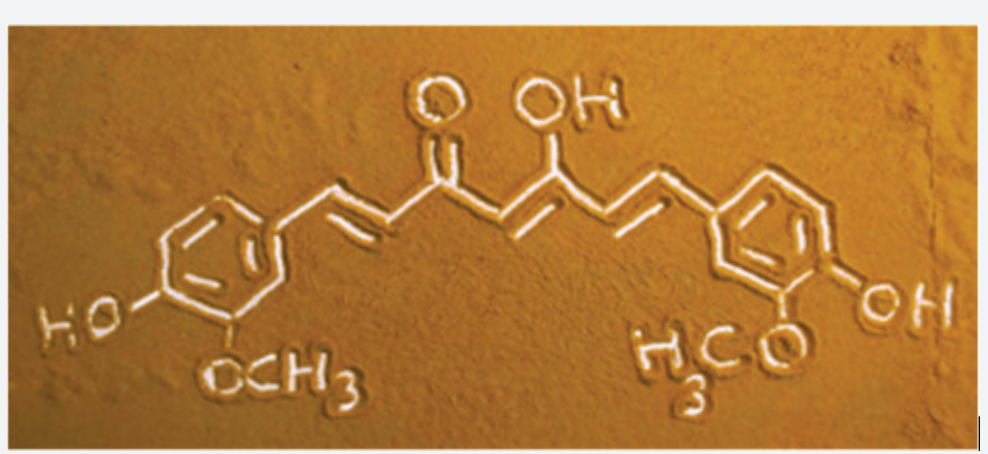

Figure 4: Structure of Curcumin (curcuminoid of Curcuma longa, turmeric).

Table 2: BASANT inhibits the following WHO strains and clinical isolates of Neisseria gonorrhoeae and Candida spp. (adapted from 3).

\begin{tabular}{|c|c|}
\hline Standard WHO strains \& clinical isolates & Antibiotic resistance \\
\hline \multicolumn{2}{|l|}{ Neisseria gonorrhoeae } \\
\hline N. gonorrhoeae WHO-C & None \\
\hline N. gonorrhoeae WHO-G & Tetracycline nalidixic acid \\
\hline N. gonorrhoeae WHO-K & Penicillin (PPNG), nalidixic acid, ciprofloxacin, ceftriaxone less sensitive \\
\hline N. gonorrhoeae WHO-L & Penicillin (PPNG), nalidixic acid, ciprofloxacin, ceftriaxone less sensitive \\
\hline N. gonorrhoeae 1586 & Nalidixic acid, ciprofloxacin \\
\hline N. gonorrhoeae 1669 & Nalidixic acid, ciprofloxacin \\
\hline N. gonorrhoeae 1794 & Nalidixic acid, ciprofloxacin \\
\hline N. gonorrhoeae 2182 & Nalidixic acid, ciprofloxacin \\
\hline N. gonorrhoeae 2436 & Penicillin (PPNG), tetracycline (TRNG), nalidixic acid, ciprofloxacin \\
\hline N. gonorrhoeae 2482 & Penicillin (PPNG), nalidixic acid, ciprofloxacin \\
\hline N. gonorrhoeae 2676 & Penicillin (PPNG), tetracycline (TRNG), nalidixic acid, ciprofloxacin less sensitive \\
\hline \multicolumn{2}{|l|}{ Candida spp. } \\
\hline C. glabrata ATCC 90030 & None \\
\hline C. glabrata (7 clinical isolates) & None \\
\hline C. glabrata (2 clinical isolates) & Fluconazole, itraconazole, ketoconazole, voriconazole, amphotericin B \\
\hline C. albicans ATCC 36082 & None \\
\hline C. albicans (5 clinical isolates) & None \\
\hline C. albicans & Fluconazole, itraconazole, ketoconazole, voriconazole, amphotericin B \\
\hline C. tropicalis (2 clinical isolates) & None \\
\hline
\end{tabular}

BASANT prevented the entry of HPV16 in Hela cells as determined by John Schiller at the National Institute of Cancer Research at NIH, Bethesda [3]. BASANT also inhibited HIV as tested by Gustavo Doncel at CONRAD, USA and by Debashish Mitra at National Centre for Cell Science Pune [3]. Prof. Manoj Pastey at the University of Oregon, USA has reported that BASANT exercised inhibitory action against both CCR5 and CXCR4 tropic HIV strains [4]. Dr. Smita Kulkarni at the National Institute of
Virology Pune has found that BASANT inhibits HIV-1 replication in Epi vaginal explants model.

At the Indian Council of Medical Research Institute of Pathology, Prof. A. Mittal and colleagues, observed that BASANT inhibits completely the multiplication of Chlamydia trachomatis by direct exposure in vitro, as well as $C$. trachomatis within Hela 229 cells post infection [5]. 


\section{Effective treatment of vaginosis}
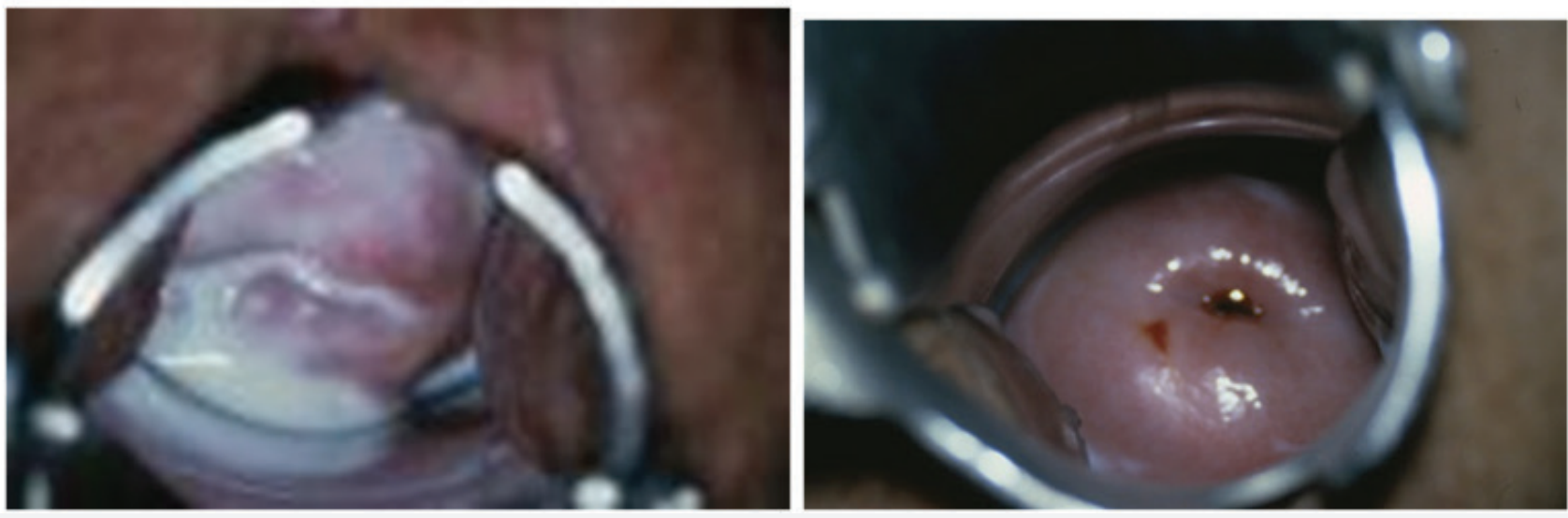

Figure 5A: Relief from abnormal vaginal discharge.
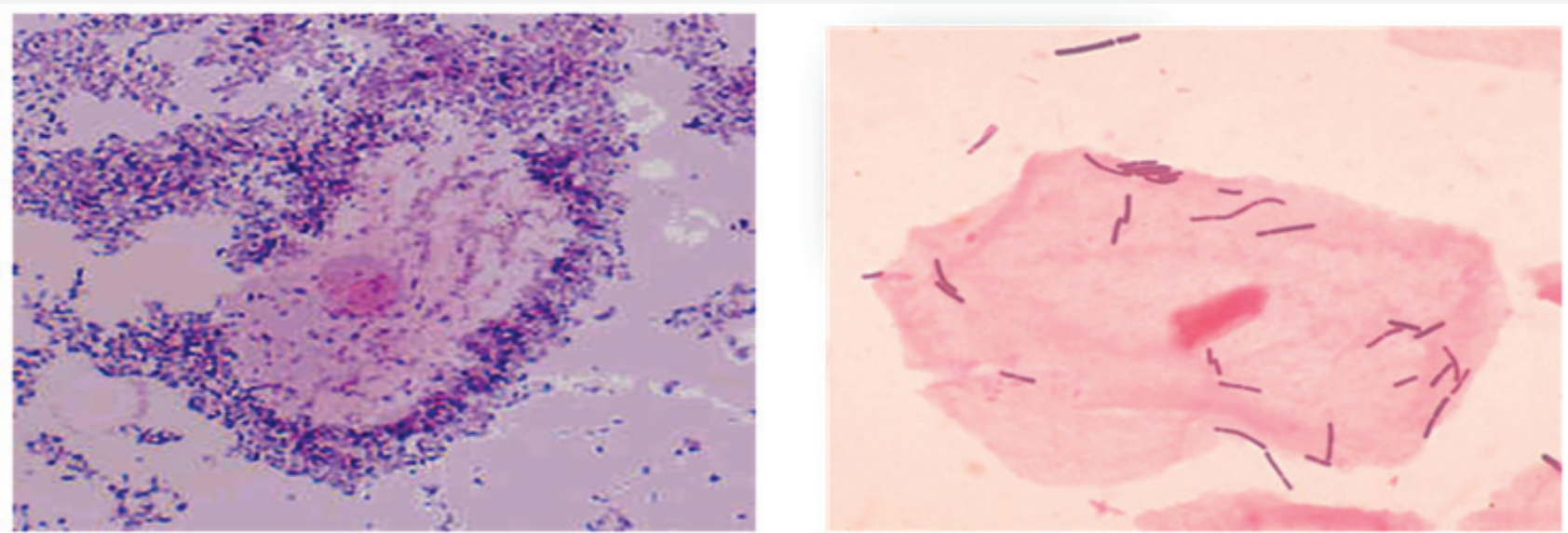

Figure 5B: Disappearance of Clue cells.

Fishy Odour

No Fishy Odour

(After $\mathrm{KOH}$ addition on slide)

(After $\mathrm{KOH}$ addition on slide)

ON ENROLLMENT

AFTER TREATMENT

Figure 5C: Healing of fishy odour

$\mathbf{p H}>5$

\section{ON ENROLLMENT}

$\mathrm{pH}<4.5$

\section{AFTER TREATMENT}

Figure 5D: $\mathrm{pH}$ of vagina restored to acidic range.

Figure 5: An illustrative representation of a typical woman receiving the treatment with combination of BASANT plus Pro-vag-Health (adapted from 6). 
With approval of the Drugs Controller General of India and Institutional Ethics Committees, Phase II clinical trials were conducted at the All India Institute of Medical Sciences, New Delhi and Sir Gangaram Hospital, New Delhi in 80 women suffering from recurring episodes of Vaginosis with vaginal $\mathrm{pH}>5$. The ability of the 3 selected meritorious Probiotics, the polyherbal formulation BASANT, and the combination of the two to clear Vaginosis and restore the $\mathrm{pH}$ of vagina to 4.5 or below, was tested. Figure 5 shows the main clinical observations on patients before and after treatment with Probiotics+ BASANT.

Table 3 gives summary of the results. It would be noted that while both the selected 3 Probiotics named as Pro-vag-Health, as well as the polyherbal microbicide BASANT, are effective in causing remission of $65-70 \%$ of patients, the combination of the two, cured nearly every patient, 19/20 (95\%) get relieved.

Table 3: Summary of results of treatment with either Probiotics, BASANT or a combination of BASANT and Probiotics to cure Vaginosis and restore reproductive health (adapted from 6).

\begin{tabular}{|c|c|c|c|c|}
\hline Group Name & Women Enrolled & Improved (\%) & $\begin{array}{c}\text { P Value Comparison With } \\
\text { Placebo }\end{array}$ & $\begin{array}{c}\text { P Value Comparison With } \\
\text { Basant+Probiotics }\end{array}$ \\
\hline Probiotics & 20 & $65 \%$ & $\mathrm{P}<0.001$ & $\mathrm{P}=0.04$ \\
\hline BASANT & 20 & $70 \%$ & $\mathrm{P}<0.001$ & - \\
\hline BASANT+Probiotics & 20 & $95 \%$ & $\mathrm{P}<0.001$ & - \\
\hline Placebo & 20 & $5 \%$ & - & $\mathrm{P}<0.001$ \\
\hline
\end{tabular}

\section{Exceptional property of BASANT to eliminate HPV-16 from infected cervical cells}

Several strains of Human Papilloma Virus (HPV), notably HPV-16 and HPV-18 cause carcinogenesis of cervical cells. Carcinoma of cervix is a major cancer of women. On infection with HPV, Pap smear is rendered abnormal. Infected cells pass slowly through various stages of cervical intra-epithelial neoplasia represented as C1N1, C1N2, and so on. At early stages, the virus is in cytoplasm and not integrated in the host genome. We tried to investigate whether BASANT, the polyherbal microbicide

which prevents the entry of HPV-16 in Hela cells [3], can exercise any effect on the virus infected cells at early stages when the virus is not yet integrated in the cellular genome. This trial was conducted at the Jawaharlal Nehru Medical College, Aligarh in collaboration with the Institute of Cytology and Preventive Oncology, an Institute of Indian Council of Medical Research. One hundred fifty nine women coming to Obstetrics and Gynaecology clinic were examined clinically by visual inspection of cervix and by staining with acetic acid. Cervical scraps were collected using Ayres spatula by rotating it at $360^{\circ}$ around the circumference of the ecto-cervical region and endo-cervical canal to prepare Pap smears. On basis of inflammatory cervix and abnormal Pap smear, 35 subjects were enrolled. Out of these, 19 subjects were found positive for HPV-16. However only 11 of them agreed to undergo intra-vaginal treatment with BASANT. The treatment prescribed was insertion every night of a capsule containing $250 \mathrm{mg}$ of BASANT for 30 days, excluding the days of menstruation. Table 4 summarises the observations.
Table 4:Pre and post treatment with BASANT of HPV-16 positive patients (adapted from 7).

\begin{tabular}{|c|c|c|c|c|}
\hline \multirow{2}{*}{ S.No. } & \multirow{2}{*}{ Age } & \multirow{2}{*}{ Parity } & HPV-16 & HPV-16 \\
\cline { 3 - 5 } & & & Pre-Treatment & Post-Treatment \\
\hline 1 & 42 & $3+0$ & $+\mathrm{VE}$ & NEGATIVE \\
\hline 2 & 27 & $4+0$ & $+\mathrm{VE}$ & NEGATIVE \\
\hline 3 & 35 & $3+0$ & $+\mathrm{VE}$ & NEGATIVE \\
\hline 4 & 28 & $1+1$ & $+\mathrm{VE}$ & NEGATIVE \\
\hline 5 & 45 & $3+0$ & $+\mathrm{VE}$ & NEGATIVE \\
\hline 6 & 35 & $4+0$ & $+\mathrm{VE}$ & NEGATIVE \\
\hline 7 & 30 & $2+1$ & $+\mathrm{VE}$ & NEGATIVE \\
\hline 8 & 45 & $2+0$ & $+\mathrm{VE}$ & NEGATIVE \\
\hline 9 & 38 & $5+2$ & $+\mathrm{VE}$ & NEGATIVE \\
\hline 10 & 35 & $3+1$ & $+\mathrm{VE}$ & NEGATIVE \\
\hline 11 & 38 & $3+1$ & $+\mathrm{VE}$ & NEGATIVE \\
\hline
\end{tabular}

It would be noted that every patient, 11/11 became HPV16 negative after 30 days exposure to BASANT. While BASANT prevents the entry of HPV-16 in Hela cells, its ability to eliminate HPV-16 from infected cells at early stages of C1N1, when virus is not yet integrated in the cellular genome, is a valuable trait.

\section{Summary and Conclusion}

Reviewed briefly are 2 Products developed in our laboratory. Both have bearing on vaginal health. Pro-vag-Health capsules contain lyophilized and stabilized 3 selected Lactobacillus strains, which make and secrete high amounts of Lactic acid, are hydrophobic to colonize easily in vagina of recipients. By virtue 
of the enzyme Arginine deiminase, they prevent the formation of foul odour derivatives. These restore the $\mathrm{pH}$ of the vagina to 4.5 or below.

The Polyherbal microbicide BASANT has antimicrobial action on N. gonorrhea, various species of Candida, Chlamydia trachomatis, HPV and HIV. While both BASANT and Pro-vagHealth probiotics have curative action on recurring episodes of Vaginosis, the combination of the two is effective in nearly every woman, $95 \%$ of cases, the highest reported so far in literature.

BASANT has also the exceptional property of eliminating HPV-16 from infected cervical cells.

\section{Acknowledgement}

The work recapitulated in this review received financial support from the Indian Council of Medical Research and the Department of Biotechnology, Govt of India.

\section{References}

1. Garg KB, Ganguli I, Das R, Talwar GP (2009) Spectrum of Lactobacillus species present in healthy vagina of Indian women. Indian J Med Res 129(6): 652-657.
2. Garg KB, Ganguli I, Ram Das, Kriplani A, Lohiya NK, et al. (2009) Metabolic properties of lactobacilli in women experiencing recurring episodes of bacterial vaginosis with vaginal $\mathrm{pH} \geq 5$. Eur J clin Microbiol Infect Dis 29: 123-125.

3. Talwar GP, Dar SA, Rai MK, Reddy KV, Mitra D, et al. (2008) A novel Polyherbal microbicide with inhibitory effect on bacterial, fungal and viral genital pathogens. Int J Antimicrob Agents 32(2): 180-185.

4. Maselko MB, Joshi RS, Prescott MA, Talwar GP, Kulkarni S, et al. (2014) A Polyherbal Topical Microbicide Candidate Inhibits Different Clades of Both CCR5 and CXCR4 Tropic, Lab-Adapted and Primary Isolates of Human Immunodeficiency Virus-1 in Vitro Infection. J Virol Antivir Res 3: 3 .

5. Bhengraj AR, Dar SA, Talwar GP, Mittal A (2008) Potential of a novel polyherbal formulation BASANT for prevention of Chlamydia trachomatis infection. Int J Antimicrob Agents 32(1): 84-88.

6. Kriplani A, Sehgal R, Atrey N, Singh P, Ganguli I, et al. (2014) Clinical evaluation of comparative and combined effect of Polyherbal Microbicide (Basant) and selected probiotics in the treatment of recurrent Vaginosis -a Phase II placebo controlled trial. Int J Ayur Pharma Res 2(4): 33-41.

7. Talwar GP, Sharma R, Singh S, Das BC, Bharti AC, et al. (2015) BASANT, a Polyherbal Safe Microbicide Eliminates HPV-16 in Women with Early Cervical Intraepithelial Lesions. J Cancer Ther 6: 1163-1166.

\section{Your next submission with Juniper Publishers} will reach you the below assets

- Quality Editorial service

- Swift Peer Review

- Reprints availability

- E-prints Service

- Manuscript Podcast for convenient understanding

- Global attainment for your research

- Manuscript accessibility in different formats ( Pdf, E-pub, Full Text, Audio)

- Unceasing customer service

Track the below URL for one-step submission https://juniperpublishers.com/online-submission.php 